\title{
Abortion Due to Rape in The Perspective of Criminal Law and Health Law in Indonesia
}

\author{
Tongat* Isdian Anggraeny \\ Faculty of Law of Muhammadiyah Malang University, Raya Tlogomas Street Number 246, Malang, Indonesia
}

\begin{abstract}
The legalization of abortion as a result of rape in Law Number 36 Year 2009 Concerning Health, has caused a long debate. The debate is divided into at least two opposing views. First, the view that supports the abortion caused by rape. This group holds that abortion due to rape can be tolerated on humanitarian grounds. This view is based on the idea that the criminalization of women abortionists as a result of rape is a form of discrimination against women victims of rape. Second, the view that refuses abortion due to rape. This group is of the view that fetuses in the womb of women still have the right to life. According to this view, abortion can only be performed on medical indication. The following article will carry two issues as a reference for discussion. First, how is abortion caused by rape constructed in positive law in Indonesia? Second, how is the legal consequence of the decriminalization of abortion as a result of rape in health law in Indonesia? Through normative studies, this study produces conclusions as follows. First, in the perspective of positive law in Indonesia, abortion is in principle a prohibited act. Second, the decriminalization of abortion due to rape in health law is a response to emergencies, not valid in all circumstances.
\end{abstract}

Keywords: abortion, rape, criminal law, health law

DOI: $10.7176 / \mathrm{JLPG} / 103-02$

Publication date: November $30^{\text {th }} 2020$

\section{Introduction}

There are two phenomena that lie behind the theme of abortion due to rape to be interesting to study. First, to this day there is a constant tendency for high abortion in Indonesia. Although legally formal, abortion is a prohibited act in criminal law, abortion is still rife in Indonesia. The number of abortion cases in Indonesia each year reaches 2.3 million cases (Kompas.com, 2009). Other sources say the figure is up to 3 million per year (Utami \& Mulyana, 2017). Judging from the numbers, abortion cases that occur are very alarming. For this reason, the author is interested in talking about abortion in Indonesia in particular from the perspective of criminal law and health law. Secondly, there is a tendency to continue with the high incidence of rape in Indonesia, although efforts to increase criminal sanctions continue. The high level of rape is also interesting to be studied, especially if it is related to the number of abortions in Indonesia. Bearing in mind, some of the abortions that were carried out were due to rape. Komnas Perempuan for example noted, in 2016 to 2018 there were 17,088 cases of sexual violence in Indonesia. Of the 17,088 cases of sexual violence, there were 8,797 rape cases or 52 percent of the total sexual violence cases.(Kompas.com, 2009) Indeed, from the number of rapes there is no explanation of what percentage resulted in pregnancy and abortion. However, the rape rate is quite interesting to study in relation to abortion.

If related to global conditions, the issue of abortion is also in the spotlight due to the high rate of abortion throughout the world. Abortion is even considered to be the biggest cause of death in the whole world. The death rate due to abortion is far higher than the mortality rate due to HIV / AIDS. It was based on surveys and research conducted by the World do meter, the American Library Association (ALA) or the American librarians association. They reported that deaths by abortion reached 41.9 million people in one year during 2018. While deaths caused by cancer were only 8.2 million people. Then 5 million people also died from cigarette smoke and 1.7 million people died from HIV / AIDS.(Kompas.com, 2009) Taking into account her background, it is quite relevant to talk about abortion as a result of rape in Indonesia

\section{Abortion due to rape in the perspective of criminal law in Indonesia}

Sociologically, there are actually so many reasons for a woman to have an abortion. Quarterly Point mentions several reasons for a woman to have an abortion, for example, wanting to continue her education, because of fear and shame on her parents and social environment, not ready to get married, obey the prohibition of marriage during the contract period, and the reason for rape (Tutik, 2010). Quraish Shihab, as quoted by Duhriah also stated, that aborters in the modern era of ignorance, some of them had abortions not because they were afraid of being poor, but because they were caused to cover up the shame that befell them after an accident due to their mother's sins. In the days of ignorance, they killed their children for fear of being raped or adultery, but nowadays the mothers themselves are raped or have committed adultery (Duhriah \& Yati, 2019). In the perspective of Indonesian criminal law, tolerance is not known for abortion due to rape. In the perspective of Indonesian criminal law, abortion for any reason is prohibited, (Tongat, 2003) (Anwar, 1994) (Bassar, 1986) 
(Chazawi, 1999) except for medical indications.

Therefore, in the Indonesian Penal Code there are no exceptions regarding the prohibition on abortion. Related to the issue of abortion, Indonesia's criminal law adheres to a regime of prohibitions by prohibiting all forms of abortion without exception.(Soge, 2009) In the Criminal Code, abortion is known as a miscarriage or homicide. Such a view of the Criminal Code is in line with Sharon J. Reeder as quoted by Rinna Dwi Lestari : "Abortion is the termination of pregnancy at any time before the fetus has attained a stage of viability". Abortion, known as abortion, is the termination of a pregnancy or removal of the fetus from the womb when the fetus experiences interference in a certain phase of pregnancy before the fetus can live outside the womb.(Lestari, 2020) According to Nani Soendo, abortion is the release of the fruit of pregnancy when the fetus is still so small that it cannot live (Yusriana, 2015). As the name implies, the crime of abortion or murder is an offense for which the object is womb. The term content in the context of this crime refers to the notion of content that has been in the form of a human being or content that has not yet taken the form of a human being. Precisely because of the two forms of the content of the crime that occurred can be in the form of an abortion which means abortion or abrogation or murder which means the killing or killing of the womb. This view is also in line with the stages of human creation according to Islamic teachings which state: "And We have created humans from an essence (derived from ) from the ground. Then We made the essence of semen (stored) in a firm place (womb). Then the semen We made a clot of blood, then a clot of blood We made a lump of flesh, and We made a lump of meat We made bones, then We wrapped the bones with flesh. Then We made him another being. So Glory is to Allah, the Best Creator. Then, after that, your people will die. Then, verily all of you will be raised (from your graves) on the Day of Resurrection "(QS: Al Mu'minun: 12-16). The criminal act of abortion or homicide as stipulated in the Criminal Code consists of 4 types of criminal acts, namely:

1. The criminal act of abortion or homicide committed by the self, which is regulated in article 364 of the Criminal Code.

2. The criminal act of abortion or homicide committed by another person without the consent of the woman herself, regulated in article 347 of the Criminal Code.

3. The criminal act of abortion or homicide committed by another person with the consent of a pregnant woman, is regulated in article 348 of the Criminal Code.

4. The criminal act of abortion or homicide committed by another person of a certain quality, namely a doctor, midwife or drug remedy whether committed by the woman's consent or not with the woman's consent, is regulated in Article 349 of the Criminal Code.

Noting the articles in the Criminal Code that govern abortion it is very clear that Indonesian criminal law essentially prohibits all forms of abortion without exception. In contrast to Indonesia, some countries, such as Egypt, allow the practice of abortion or sterilization on the grounds of poverty and health factors (Rizal, 2015). If the prohibition of abortion in the Criminal Code is related to abortion due to rape, then abortion due to rape in the perspective of the Criminal Code can be done by the woman herself, carried out by someone else without the woman's own consent, carried out by another person with the woman's own consent or carried out by someone else who have certain qualities, such as a doctor, midwife or drug interpreter whether done with the woman's approval or not with the woman's consent. All forms of abortion are prohibited and prohibited acts. Thus, abortion as a result of rape, whether committed by the woman herself or carried out by another person either with her consent or without her consent, is prohibited.

To provide an overview of abortion in the perspective of criminal law, the following briefly stated about the construction of abortion according to the Criminal Code. As mentioned in the previous section, in the Criminal Code abortion is equated with the crime of abortion or homicide. Therefore, in the description below will be discussed about what is meant by abortion and turn off the content. The explanation of these two terms is very urgent, bearing in mind the essence of the crime of abortion precisely because of these two acts. The term " abortion " literally means being born prematurely. Thus, aborting the content implies aborting or canceling the content until the content does not arrive in time (naturally). In countries that adhere to the Common Law system such as the UK, limiting the meaning of abortion to unviable fetuses. Meanwhile, efforts to remove the fetus when the fetus is viable ( 28 weeks gestation or more) is called Child Destruction, which carries a heavier penalty than abortion (Sembiring \& Asan, 2019) In the context of article 346 of the Criminal Code abort the content it means that every action to cancel the content or make the content, not until the time naturally. In other words, abortion implies understanding, aborting or canceling the birth naturally.

Starting from this meaning, aborting the womb basically contains the intention to abort birth naturally, which basically contains the intention that the baby or fetus contained in the womb is prematurely born naturally. Thus, it can be briefly concluded, that aborting the womb is to do every act against the womb in question so that the fetus is born prematurely naturally. Popular actions intended to force the fetus out or born prematurely are called provocate abortion. In connection with the element of abortion, it is worth mentioning, that the fetus born or left as a result of the act of abortion is not questioned whether the fetus after leaving the woman is alive or dead. In this case the act of aborting the womb is considered to have occurred or is completed with the birth of 
the fetus or the baby without questioning whether the fetus after birth is alive or dead.

However, it should be noted that even if the problem of life or death of the fetus after birth is not a problem, but the state of the fetus before birth or when it is still in the womb must be proven alive. This is because if the fetus is dead before birth or is already dead while still in the womb, then it is not possible to have a miscarriage or homicide. This understanding is based on systematic interpretation, where the crime in article 346 of the Criminal Code is under the chapter on crimes against life. Precisely for this reason, it is not possible to have a crime against the life of a dead or lifeless creature. Logically too, it is not rational if the act of abortion of a dead content is made a criminal offense. Precisely if the fetus has died in the womb, it must be aborted for the safety of the pregnant mother. Thus, looking at this logic it is impossible to have a miscarriage if the fetus when in the womb is dead. Abortion is a crime after it can be proven, that the fetus in the womb is still alive. This understanding is in line with developing jurisprudence, especially those that contained in Arrest Hooge Raad on November 1, 1987 which in essence said, abortion can only be criminalized, if at the time the act was carried out the womb was still alive.

The term is deadly in essence is every action that results in the death of the fetus in the womb of a woman.(Chazawi, 1999) In other words it can be said, that it kills the life (fetus) in a woman's womb. As a condition for the act of aborting a womb that is criminal, then for the existence of an act deadly contains that a criminal nature must also be proven, that the fetus in the womb of a woman must live. Proof of course that must be done by those who are competent, namely doctors. In contrast to the act of aborting the womb of a woman who does not question the fetus or baby after birth, then in the act of killing the womb, the fetus must die after birth. Because, precisely the act of killing the uterus, a new woman is considered to have finished if the consequences of the death of the fetus have occurred. Without the death of the fetus after birth, the act of killing the uterus is considered not to have occurred.

\section{Abortion due to rape in the perspective of health law in Indonesia}

Unlike the perspective of criminal law, health law has its own perspective in seeing abortion. In the perspective of the principle of enactment of the law, the health law - in this case Law Number 36 of 2009 on Health - can be seen as a lex specialist of the Criminal Code. In the perspective of Law Number 36 Year 2009 Concerning Health, certain abortion can be carried out. That is, according to Law Number 36 Year 2009 Regarding Health if it meets the conditions required, then an abortion is legally carried out. That is, an abortion may be allowed. Exceptions to abortion in Law Number 36 Year 2009 Concerning Health are stipulated in the provisions of Article 75 which expressly states:

(1) Everyone is prohibited from having an abortion.

(2) Prohibitions as referred to in paragraph (1) may be excluded based on:

a. indications of medical emergencies detected since early pregnancy, both those that threaten the lives of mothers and / or fetuses, who suffer from severe genetic diseases and / or congenital defects, or which cannot be repaired making it difficult for the baby to live outside the womb; or

b. pregnancy due to rape which can cause psychological trauma for rape victims.

(3) The actions referred to in paragraph (2) can only be done after going through pre-action counseling and / or counseling and ending with post-action counseling carried out by competent and authorized counselors.

(4) Further provisions regarding indications of medical emergencies and rape, as referred to in paragraph (2) and paragraph (3) shall be regulated by Government Regulation.

The provisions of Article 75 paragraph (1) of Law Number 36 Year 2009 concerning Health above confirms that in principle, abortion must not be carried out by anyone. This means that in principle Law Number 36 Year 2009 regarding Health also does not allow abortion. This principle is actually also in line with the provisions in the Criminal Code which in principle prohibits all forms of abortion. However, the provisions of Article 75 paragraph (1) in Law Number 36 of 2009 concerning Health do not apply absolutely. The next provision is the provisions in Article 75 paragraph (2) opening the space for the possibility of an abortion. The provisions of Article 75 paragraph (1) which prohibit all forms of abortion are deviated by the provisions of Article 75 paragraph (2) which gives the possibility of an abortion if there are conditions specified in paragraphs $\mathrm{a}$ and $\mathrm{b}$ of Article 75 paragraph (2). Circumstances that can exclude prohibitions in the provision of Article 75 paragraph (1) include:

First, medical emergencies. In the Indonesian Big Dictionary, the term emergency implies unexpected (difficult) difficult conditions (in danger, hunger, etc.) that require immediate relief, forced conditions, temporary conditions.(Badan Pengembangan dan Pembinaan Bahasa, 2016) Thus, according to the provisions of Article 75 paragraph (2) letter a, the prohibition of abortion can be excluded by the presence of medically difficult conditions that are dangerous. Medical emergency which is the door to exemption from the prohibition of abortion as stipulated in letter a Article 75 paragraph (2) of Law Number 36 Year 2009 concerning Health is a medical emergency that is at least eligible, namely medical emergencies detected from an early age of pregnancy, both life-threatening mothers and / or fetuses, who suffer from severe genetic diseases and / or 
congenital defects, or which cannot be repaired making it difficult for the baby to live outside the womb. With these provisions, not all medical emergencies can be an exception for an abortion.

Second, pregnancy due to rape can cause psychological trauma for rape victims. Pregnancy that can override the analogy ban is pregnancy caused by rape which can result in psychological trauma. That is, not necessarily pregnancy due to rape is also an exception to abortion. But only pregnancy due to rape causes psychological trauma. The provisions of Article 75 paragraph (2) letter b indicate, a high degree of caution in providing space for abortions due to rape. The precautionary nature of the provisions of Article 7 paragraph (2) letter $b$ really indicates that abortion due to rape is a door that is very emergency. The provisions of Article 7 paragraph (2) letter b as an emergency exit are important to understand, so as to reduce the level of abortion in Indonesia, which tends to increase. Understanding the provisions of Article 7 paragraph (2) letter b is also important to avoid the assumption that abortion is assumed to be the only way out of all pregnancies due to rape.

Based on the provisions of Article 7 paragraph (2), both letter a and letter b read clearly, that medical emergencies and pregnancy due to rape do not automatically become the reason for abortion. Only medical emergencies and pregnancy due to rape that meet certain conditions can be the reason for an abortion. The provisions of Article 7 paragraph (2) both letter a and letter b are strengthened by the provisions of Article 7 paragraph (3) whereby an abortion can be carried out for reasons as referred to in Article 7 paragraph (2) only after counseling and / or pre counseling actions and end with post-action counseling carried out by competent and authorized counselors. The provisions of Article 7 paragraph (3) clearly reiterate that abortion - both for reasons of medical emergencies and pregnancy due to rape - cannot be carried out immediately. The provisions of Article 7 paragraph (3) of Law Number 36 Year 2009 Concerning Health provides an emergency exit for an abortion, but at the same time ensures that the emergency door used medically is safe. Because, if an abortion is not performed safely, will endanger both the mother and the fetus. WHO predicts that $10-50 \%$ of unsafe abortion cases end in maternal death. It is estimated that every year around the world there are about 20 million unsafe abortions. Of these, $26 \%$ of abortion practices are legal and more than 70,000 unsafe abortions in developing countries end in maternal death.(Atalim, 2011)

The provisions of Article 75 paragraph (3) also constitute a middle point of conflict that defends the right to live the fetus on the one hand and defends the interests of women who conceive on the other side. The point of "contention" and the polarization of this difference of view is extreme defense of the right to life of the fetus (embryo) or defense against the interests of pregnant women. This point has led to a "fight" between the prochoice and pro-life camps in dealing with abortion.(Atalim, 2011). Polarization is also seen from the view that children are a gift from God who has the right to live. They are of the view that the fetus has the right to life which cannot be taken by anyone, including the mother who is carrying it. Having an abortion is tantamount to committing murder, and murder is a very big sin.

\section{Conclusion}

Based on this brief presentation, it can be concluded that in the perspective of positive law in Indonesia - namely criminal law and health law - in principle, abortion is prohibited. Both in criminal law and in health law the principle of abortion is an act that is against the law. That is, abortion is not permitted. The possibility of allowing an abortion according to health law is an emergency door to deal with the possibility of an emergency, both medical emergencies and pregnancy emergencies due to rape. Conditional decriminalization in health law is a response to emergencies, does not apply in all circumstances. Because it doesn't need to be contested.

\section{References}

Anwar, m. (1994). Hukum pidana bagian khusus (kuhp buku ii. Bandung: citra aditya bakti.

Atalim, s. (2011). Perspektif moralitas dalam perkara aborsi. Jurnal yudisial, 4(3), 308-323. Retrieved from https://jurnal.komisiyudisial.go.id/index.php/jy/article/view/185

Badan pengembangan dan pembinaan bahasa. (2016). Hasil pencarian - kbbi daring. Retrieved november 9, 2020, from kbbi daring website: https://kbbi.kemdikbud.go.id/entri/darurat

Bassar, m. S. (1986). Tindak-tindak pidana tertentu di dalam kitab undang-undang hukum pidana. Bandung: remadja karya.

Chazawi, a. (1999). Kejahatan terhadap tubuh dan nyawa. Malang: bkbh fakultas hukum universitas brawijaya.

Duhriah, d., \& yati, f. (2019). Aborsi bagi wanita hamil akibat pemerkosaan. Sakena: jurnal hukum keluarga, $4(1), 21-32$. Retrieved from http://journal.fs.uinib.ac.id/index.php/sakena/article/view/170

Kompas.com. (2009). 2,3 juta kasus aborsi per tahun, 30 persen oleh remaja. Retrieved november 9, 2020, from kompas.com website: https://regional.kompas.com/read/2009/02/16/11310897/2.3.juta.kasus.aborsi.per.tahun..30.persen.oleh.rem aja

Lestari, r. D. (2020). Magistra law review. Magistra law review, 1(01), 1-22. Retrieved from http://jurnal.untagsmg.ac.id/index.php/malrev 
Rizal, f. (2015). Hak-hak kesehatan reproduksi dalam islam dan aborsi. Tafáqquh: jurnal penelitian dan kajian keislaman, 3(2), 37-56. Retrieved from http://jurnal.iaibafa.ac.id/index.php/tafaqquh/article/view/46

Sembiring, e., \& asan, p. (2019). Majalah kedokteran nusantara: the journal of medical school. The journal of medical school (jms), 52(2). Retrieved from https://talenta.usu.ac.id/tjms/issue/view/289

Soge, p. (2009). Legalisasi aborsi di indonesia perspektif perbandingan hukum pidana: antara common law system dan civil law system. Jurnal hukum ius quia iustum, 16(4), 497-514. Https://doi.org/10.20885/iustum.vol16.iss4.art4

Tongat. (2003). Hukum pidana materiil: tinjauan atas tindak pidana terhadap subyek hukum dalam kitab undang-undang hukum pidana. Jakarta: djambatan.

Tutik, t. T. (2010). Analisis hukum islam terhadap praktik aborsi bagi kehamilan tidak diharapkan (ktd) akibat perkosaan menurut undang-undang nomor 36 tahun 2009 tentang kesehatan. Jurnal hukum \& pembangunan, 40(2), 218. Https://doi.org/10.21143/jhp.vol40.no2.222

Utami, t. K., \& mulyana, a. (2017). Tanggung jawab dokter dalam melakukan aborsi tanpa seijin ibu yang mengandung atau keluarga dalam perspektif hukum positif di indonesia. Jurnal hukum mimbar justitia, 1(2), 499. Https://doi.org/10.35194/jhmj.v1i2.37

Yusriana, y. (2015). Aborsi dalam perspektif hukum islam. Jurnal ilmiah penegakan hukum, 2(1), 48-51. Https://doi.org/10.31289/jiph.v2i1.1862

Tongat, was born in Banjarnegara, January 13th, 1967, completed the undergraduate degree from Faculty of Law at Sudirman University in 1991, graduated master degree from Graduate Program at the Diponogoro University, and pass doctorate degree of Legal Studies Doctoral Program at the Diponegoro University. He Currently working as a Lecturer and Dean at the Faculty of Law, University of Muhammadiyah Malang. The author can be contacted by email: tongat_umm@yahoo.co.id or tongat@umm.ac.id

Isdian Anggraeny, was born in Batam, February 9th, 1989, completed the undergraduate degree from Faculty of Law at University of Brawijaya in 2011, and graduated master degree from program Master of Notary at Brawijaya University in 2014. She currently works as a lecturer at the Faculty of Law, Muhammadiyah Malang University. The author can be contacted by email: isdian@umm.ac.id 